This is an Open Access article, distributed under the terms of the Creative Commons Attribution licence (http://creativecommons.org/licenses/by/4.0/), which permits unrestricted re-use, distribution, and reproduction in any medium, provided the original work is properly cited.

\title{
Burial Mounds, Ard Marks, and Memory: A Case Study from the Early Iron Age at Bamble, Telemark, Norway
}

\author{
Christian Løchsen RødsRud \\ Museum of Cultural History, University of Oslo, Oslo, Norway
}

The point of departure for this article is the excavation of two burial mounds and a trackway system in Bamble, Telemark, Norway. One of the mounds overlay ard marks, which led to speculation as to whether the site was ritually ploughed or whether it contained the remains of an old field system. Analysis of the archaeometric data indicated that the first mound was related to a field system, while the second was constructed 500-600 years later. The first mound was probably built to demonstrate the presence of a kin and its social norms, while these norms were renegotiated when the second mound was raised in the Viking Age. This article emphasizes that the ritual and profane aspects were closely related: mound building can be a ritualized practice intended to legitimize ownership and status by the reuse of domestic sites in the landscape. Further examples from Scandinavia indicate that this is a common, but somewhat overlooked, practice.

Keywords: ard marks, burial mounds, site reuse, social memory, past in the past, Early Iron Age, Norway, Scandinavia

\section{INTRODUCTION}

The choice of a site for burial can be determined by religious and socio-cultural considerations. Prehistoric mounds are often found in connection with good arable land close to contemporary settlements. Standing out from the norm, two burial mounds in the woods of Bamble, one covering ard marks, raise questions concerning what these mounds may have reflected. While previous research has focused on either a ritual or a profane explanation for the presence of ard marks beneath mounds, the relationship between ploughing and mound building is approached here through the discourse of social memory. It is emphasized how all spheres of life are connected when a mound is built on top of a well-known location. The placement of mortuary monuments is not random but seems to be related to previous activities on the site, connecting the domestic with the ritual sphere. The importance of archaeometry, sampling strategies, and analysis is emphasized because of its contribution to interpretations of the site.

Here, the background for the interpretations of ard marks is given, followed by a case study of the Bamble site, a discussion of the frequency and significance of ard marks under mounds in Scandinavia, and a final discussion of site reuse and the past within the past.

\section{Ard Marks}

Marks interpreted as furrows or parallel grooves placed $20-30 \mathrm{~cm}$ apart, often with 
corresponding cross ploughing, are frequently discussed in the archaeological literature. The furrows were left by primitive ploughs or ards and are often found sealed beneath later monuments and during the excavation of field systems (Hagen, 1985; Rowley-Conwy, 1987; Bradley, 2005: 25-27; Field, 2006). The first use of simple ards in Europe is traditionally dated to 3500-3300 cal BC (Kristiansen, 1990: 322; Milisauskas, 2002: 206; Bradley, 2005: 23), but Lasse Sørensen and Sabine Karg (2012) have found evidence that the introduction of domesticated animals and cereal cultivation goes back to the period 4000-3700 cal BC. The ard was used throughout the Iron Age, and the furrows discussed in this article were dated to between cal AD 130 and 340. Early ploughs/ards are thoroughly described by P.V. Glob (1951) and Jean Guilaine (1991).

The oldest photograph of prehistoric ploughmarks was taken by Georg Sarauw in 1897. These marks were present under the Iron Age barrow in Store Vildmose, Denmark. They were interpreted as the marks from a wheel in the mud (Nielsen, 1993: 165). The first person to recognize such furrows as ard marks in northern Europe was Albert Egges van Giffen (1940) in the Netherlands, soon followed by Gudmund Hatt (1941) in Denmark. In Norway, similar furrows were documented for the first time during the excavation of the Raknehaugen mound in the 1940s, although they were not recognized until the 1990s (Skre, 1997: 15).

It was not until the 1950s and 1960s that archaeologists became widely aware of fields with ard marks (Herteig, 1954; RowleyConwy, 1987; Ramqvist, 1992; Fowler, 2002: 210; Gansum, 2004, 166-68). Explicit in many of the first publications on the topic was the notion that the marks resulted from cultivation at the site of the marks (Rowley-Conwy, 1987: 263). A problem with this cultivated field hypothesis is that ard marks would be unlikely to survive because repeated ploughing would be self-cancelling (Reynolds, 1981). Based on Reynolds' argument, Peter RowleyConwy (1987) came to the conclusion that the surviving marks under burial mounds must have been a component of the mound building and not regular agriculture. Thus, the ard marks should be understood as forming part of the preparation of the site or an aspect of the funerary ritual. This 'ritual ploughing' aspect had already been mentioned by other scholars (see Nielsen, 1993: 166-67 with further references). First was Johannes Pätzold (1960), whose work was based on a broad review of North European instances of ploughmarks. His hypothesis was based on similar practices described in the Vedic Hymns (the Sutras) and also mentioned in Homer's (1955) Iliad. The Sutras, dated to approximately $500 \mathrm{BC}$, describe actions connected with burial ceremonies. The aphoristic text includes passages on the digging of turf for the mound, a ceremonial measurement and, most importantly, ploughing with several draught animals (Caland, 1896). Ritual acts of driving chariots thrice around the dead body and leading the sacrificial animals three times around the burial place are also described in book XXIII of Homer's (1955) Iliad (the funeral of Patroclus). This has been attributed to the ritual ploughing hypothesis, although ploughing is not directly mentioned as part of the burial ceremony in the passage (Pätzold, 1960; Nielsen, 1993: 166).

As a reaction to Rowley-Conwy's interpretation, Kristian Kristiansen (1990) and Henrik Thrane (1991) considered the relationship between barrows or mounds and ploughmarks as coincidental and relating to preceding settlements. They concluded that the ard marks are best preserved if the cultivation is 'fresh'. The problem remains unresolved, but research has now moved on to questions of practice and discussions of the past within the past (Gansum, 


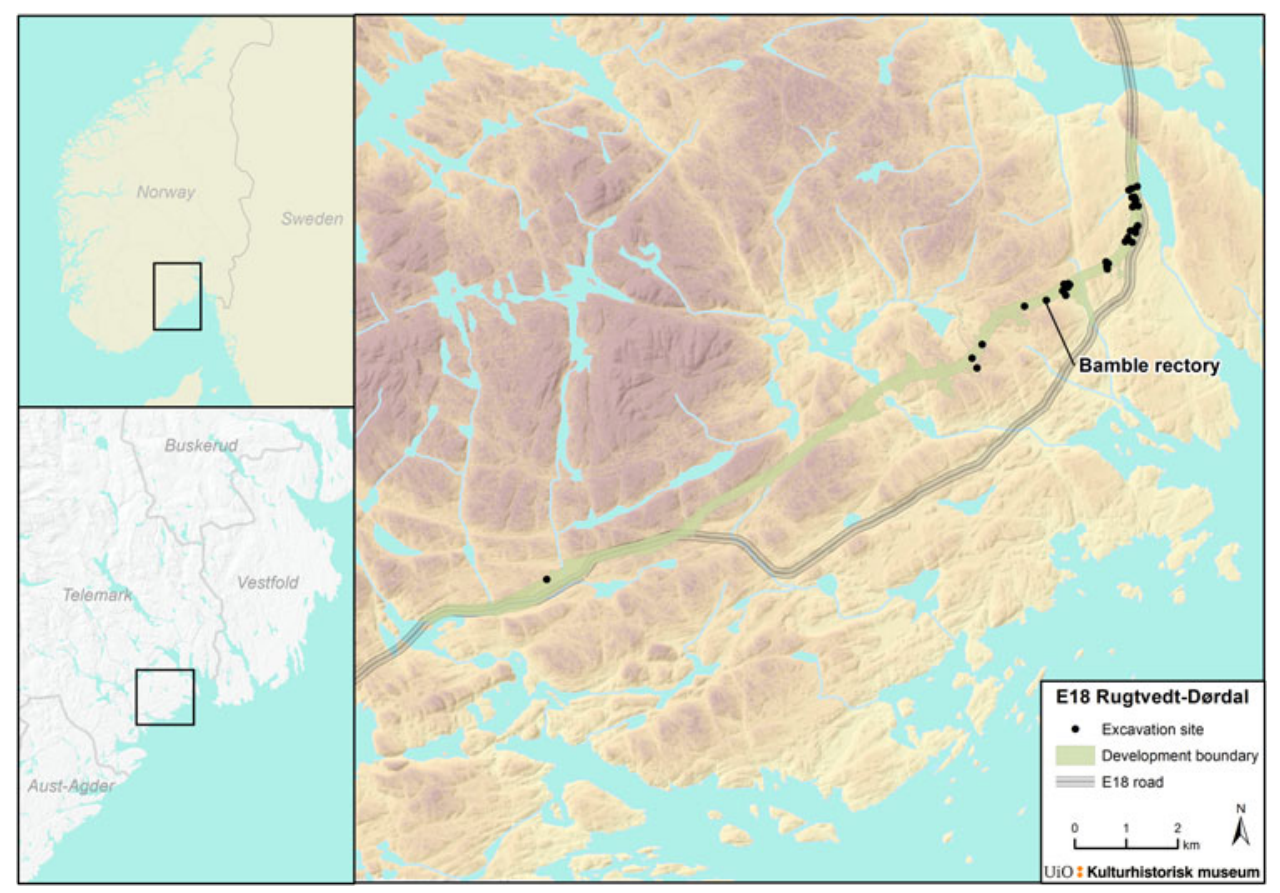

Figure 1. Location map and site of the excavations at Bamble.

2004; Thäte, 2007; Stenholm, 2012; Andrén, 2013).

\section{The Bamble Site: Mounds and Ard Marks but No Graves}

Bamble is a site with two mounds (one covering ard marks) and a trackway system located in Stillinga at Bamble prestegård (rectory) in Bamble municipality, Telemark County, Norway (Figures 1 and 2). A road construction project contracted by Statens vegvesen (the Norwegian Public Roads Administration) necessitated the excavation of the site. Stillinga is situated $2.5 \mathrm{~km}$ inland, at an elevation of $78 \mathrm{~m}$ above sea level, and was overgrown by forest at the time of excavation. The two burial mounds and the trackway system were located in a valley on a relatively flat terrace bordered by rock formations to the east and north, dense woodland to the west, and a steep ravine to the south (Figures 2 and 3). From north to south, a wetland area runs through the terrace, across the trackways, just east of the burial mounds. The wetland area was $1-2 \mathrm{~m}$ lower than the surface, thus hampering the journey through the landscape. The holloways had formed deep grooves on either side of the wetland area, and a corduroy track of logs and branches facilitated passage over the wetland. The two mounds lay $5 \mathrm{~m}$ apart next to the stream or bog that cuts through the site, separated by only one of the paths of the trackway system (see Figure 3).

Although monumental constructions, neither of the mounds contained any datable artefacts, and only one (Mound 2) covered ard marks. Thus, it was important to design a sampling strategy that would deepen our understanding of the mounds' landscape context. Both mounds were disturbed by robber trenches, which were dug deeply into their centres (see Figure 6). 


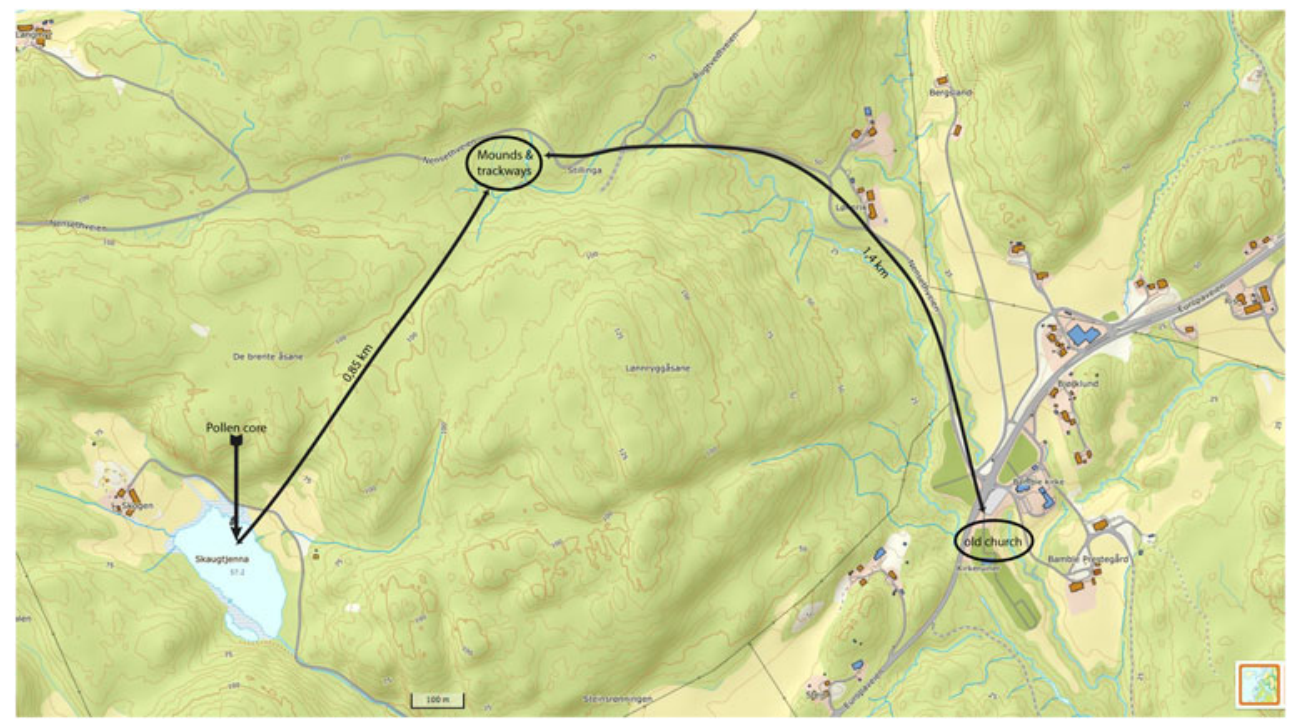

Figure 2. Map showing the excavation site, the extraction site of the pollen core, and the old church in Bamble.

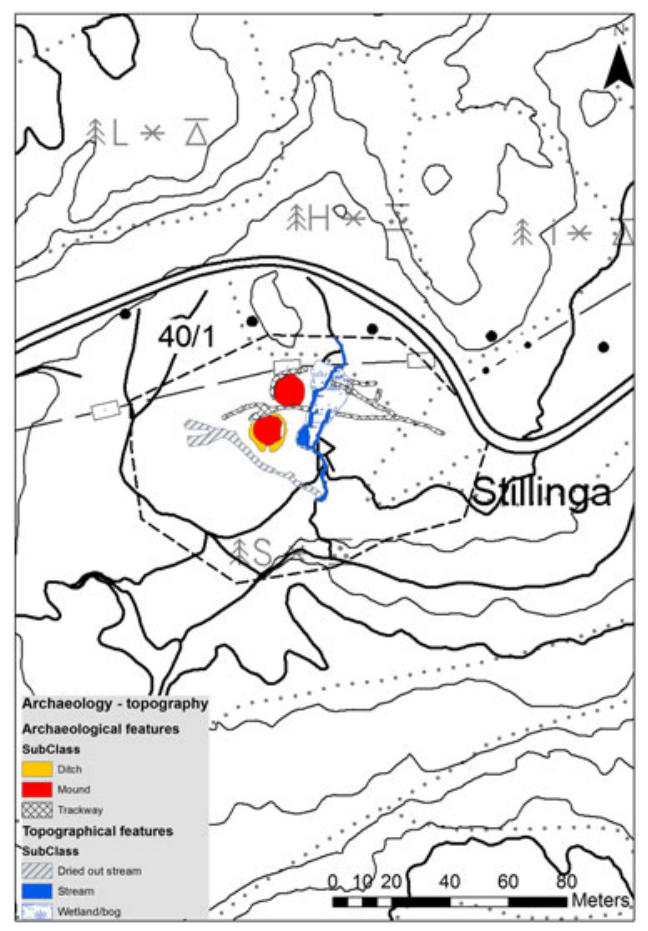

Figure 3. Topography of the Stillinga area in Bamble.
Neither of the mounds contained human remains that could be interpreted as in situ graves, and it is not possible to tell if they originally contained artefacts. Burnt human bones (weighing $13 \mathrm{~g}$ ), representing a disturbed grave, were found in the robber trench of Mound 1 and dated to cal AD 780-995 (at $2 \sigma ; 1120 \pm 28 \mathrm{BP}$, OxCal v3.10, [95.4\%]; sample Ua-51481). A supplementary sample of charcoal (hazel, corylus) was dated to cal AD 670865 (at $2 \sigma ; 1256 \pm 26 \mathrm{BP}, \mathrm{OxCal} v 3.10$, [95.4\%]; sample Ua-53185). The two samples overlap in the timespan $\mathrm{AD} 780$ 865 , indicating that the mounds were built in the early Viking Age. Mound 2 covered ard marks, but no finds of bone. However, where the robber trench stopped, there was a concentration of charcoal, cut deeper than the ard marks, possibly indicating a disturbed cremation grave or a ritual pyre (see also Figure 5). Charcoal from this concentration was dated to the Roman Iron Age (AD 1-400); its radiocarbon date, cal $\mathrm{AD} 130-330$ (at $2 \sigma ; 1787 \pm 25 \mathrm{BP}$, 


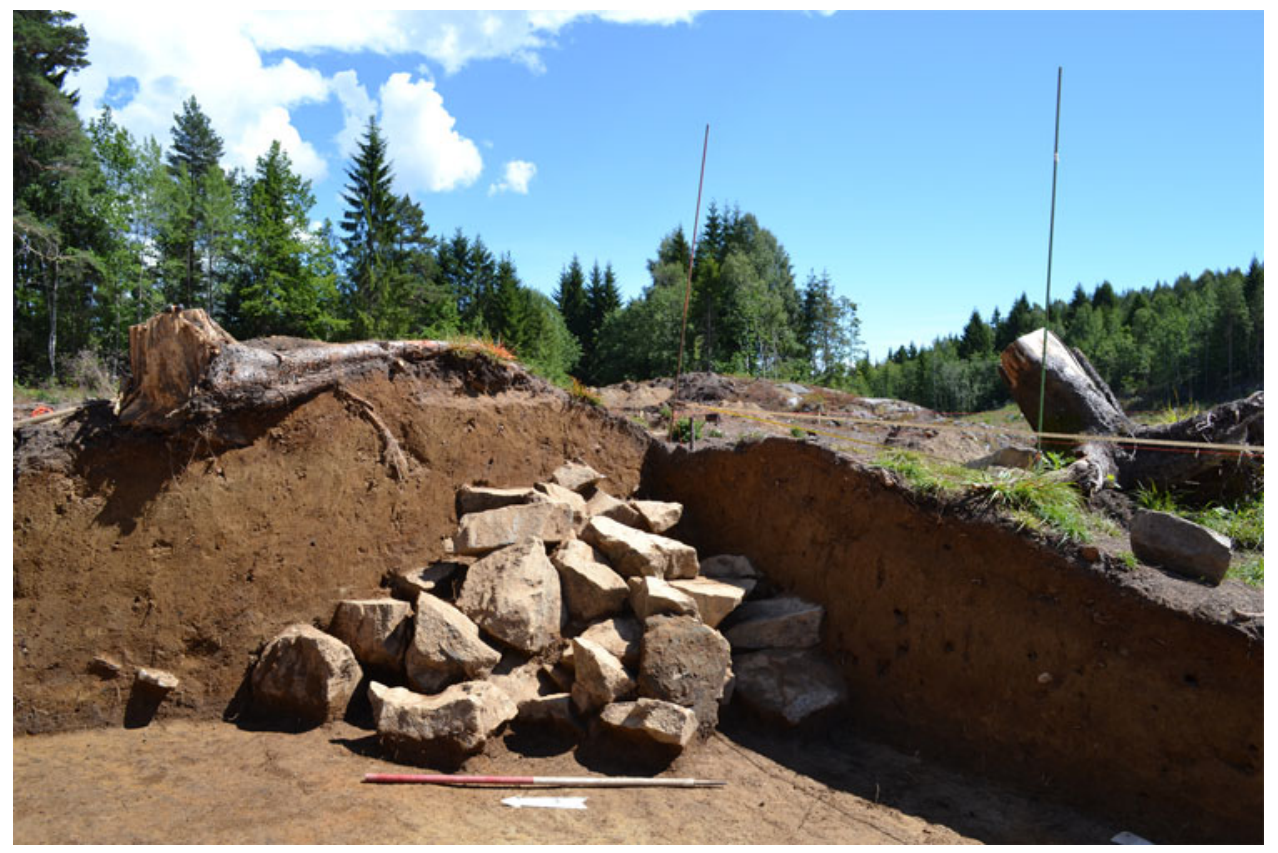

Figure 4. Mound 2 during excavation with central cairn.

OxCal v3.10, [95.4\%]; sample Ua-50503) is understood to be the date of the mound construction. In addition, humic matter was extracted from the contents of one of the ard marks under Mound 2 and dated to cal $\mathrm{AD} 130-340$ (at $2 \sigma ; 1784 \pm 32 \mathrm{BP}$, OxCal v3.10, [95.4\%]; sample Ua-50969), showing that the ard marks were quite fresh at the time of the mound building.

A mixture of forms characterizes the burial customs of eastern Norway in the Early Iron Age (AD 1-550). Mounds and cairns were common, while many graves were non-monumental and were marked only by low mounds or simple stone structures (circles, paving, etc.). At the beginning of the period, grave goods were sparse, but towards the end, graves with numerous grave goods became more common. Inhumations and cremations coexisted, but cremation was dominant. Cremations had many forms, as the ashes can be found scattered or deposited in shallow pits or urns. More rarely, the remains of cremation pyres have also been found (Munch, 1965: 40-82; Solberg, 2000: 76-78). These customs are representative of eastern Norway, but particularly the area around Bamble in Telemark. In the later Iron Age (AD 550-1050), the situation is much the same, with a wide variety of cremations but a somewhat larger number of inhumations compared to that of the Early Iron Age (Kaland, 1971: 76-140; Solberg, 2000: 186-87, 222-23).

Mound 2 was an earthen mound with a central cairn surrounded by a $1.5 \mathrm{~m}$-wide ditch (Figure 4). Ard marks appeared beneath the mound and central cairn in a regular criss-cross pattern (Figure 5). The marks seem to indicate single ploughing, and none of the furrows went beyond the surrounding ditch (Figure 6). Ritual ploughing therefore had to be considered as an interpretation, but further analysis (micromorphology and pollen sampling) showed that this was probably not the 


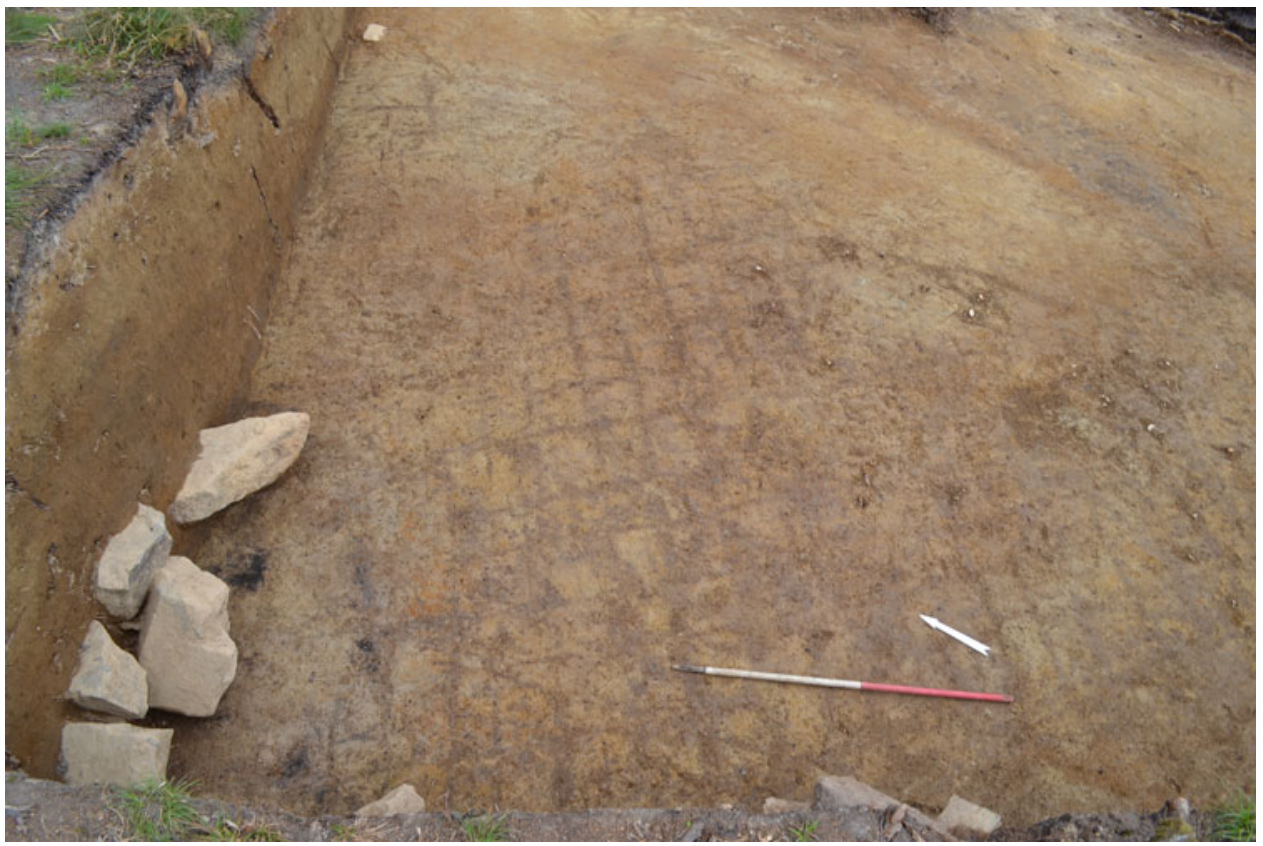

Figure 5. Ard marks beneath Mound 2 in a regular criss-crossing pattern set c. $20 \mathrm{~cm}$ apart. The concentration of charcoal to the left probably indicates a cremation.

case. Unlike Mound 2, no ard marks were found beneath the later Mound 1. Both mounds were excavated using the same methodology, mechanically removing spits of $c .5 \mathrm{~cm}$ by machine. The two mounds were built on the same type of subsoil, making it unlikely that similar ard marks would have been missed during the excavation of Mound 1 , investigated after Mound 2, meaning the excavators were aware of the phenomenon at this site. Possible ploughmarks from the rest of the site were presumably erased by natural processes over time, as will be discussed later.

To reach a better understanding of the burial contexts, extensive sampling was undertaken (Rødsrud, 2017: 584-85), including plant macrofossils from the mound material down through the buried soil and also outside the mounds (Linderholm et al., 2016). Monoliths for micromorphological analyses were taken from the same contexts as well as from the surrounding ditch, while an ard mark was sampled separately (Macphail, 2015). To understand the development of the local landscape, pollen samples were taken from beneath the mounds, the buried soil, and the mound material (Linderholm et al., 2016). Since the excavations of the two mounds were part of a large-scale project, we were also able to extract a pollen core from a nearby lake, Lake Skogtjern (Skaugtjenna, see Figure 2; WieckowskaLüth et al., 2015). Combining the regional pollen analysis from the lake with the intrasite pollen records proved useful, and all the data from the project's sampling strategy were key to the interpretation of the site.

The plant macrofossil samples did not produce any information, but the micromorphological analysis gave a first indication that the use of the landscape changed dramatically over time. At Bamble/ Stillinga, soils from all layers from both 


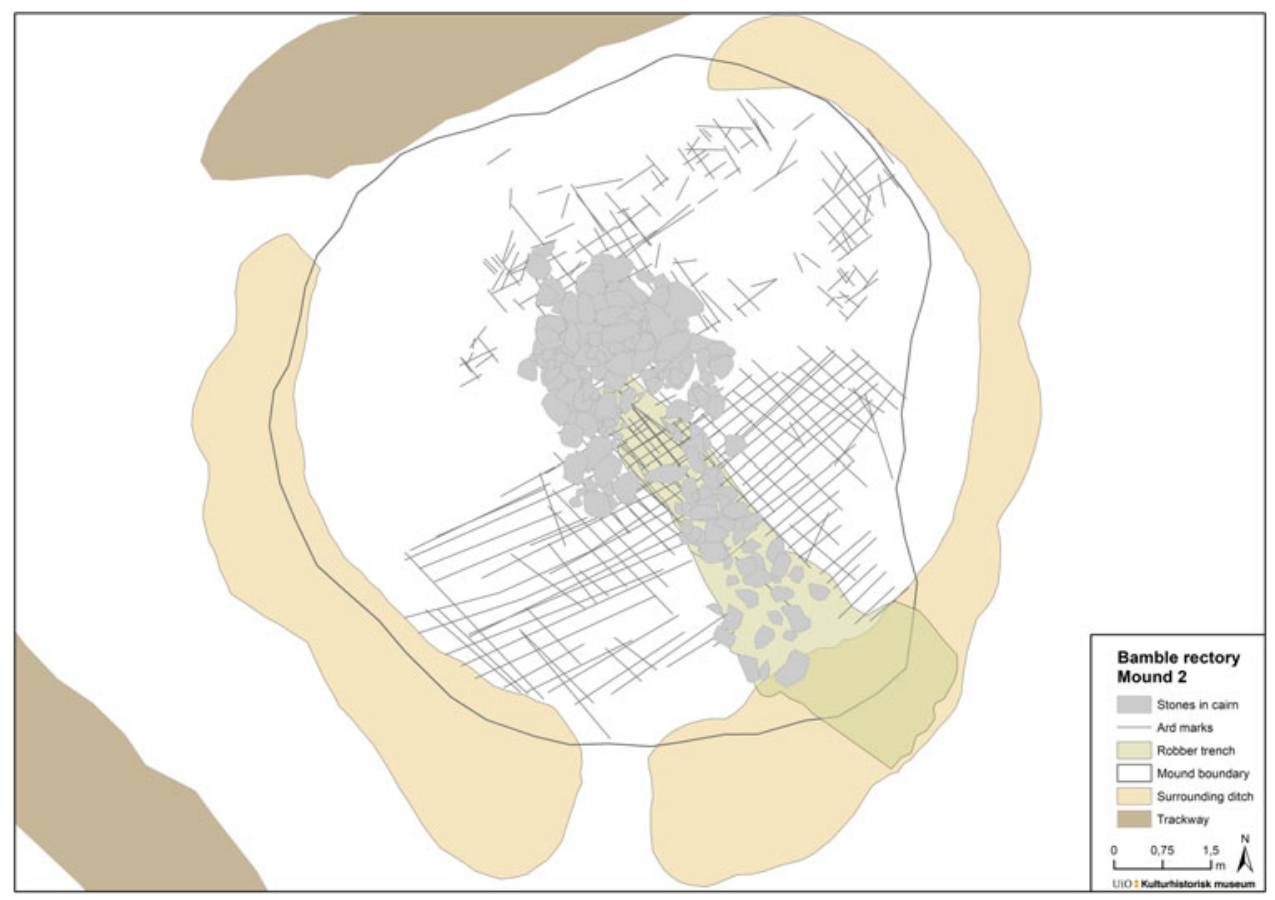

Figure 6. Plan of Mound 2 with surrounding ditch, robber trench, central cairn, and ard marks.

mounds were lightly manured with animal dung and settlement waste (burnt mineral material, iron-stained charcoal) as also reflected in an enhanced PQuota and magnetic susceptibility in the ard-marked soil (Macphail, 2015: 1, 5-7). The material to build the mounds must have come from the surrounding ditch and nearby land, suggesting that the area was used as a field. As far as is known, dung input in a ritually ploughed field has never been suggested. These findings indicate farming at the site and not just a single ploughing event. The presence of burnt settlement waste and dung possibly point to a nearby settlement associated with the field. In today's perspective, the site seems to be a marginal piece of land, but this may have been different in the Iron Age. The quality (i.e. the productive capacity) of the site west of the mounds is good, possibly making the area suitable for farming (see
Figures 3 and 7), although good soils do not necessarily imply arable use. ${ }^{1}$

The effect of an occasionally high water table is one of the main factors in site formation processes, causing the leaching, mobilization, and concentration of phosphate (Macphail, 2015: 1, 3, 15). The soils in the mounds are quite depleted, and the surrounding ditch seems to have tapped high water tables. In his micromorphology report, Richard Macphail (2015: 1, 3, 15) suggests that the high water table may have adversely affected crop yields, and possibly

\footnotetext{
${ }^{1}$ This area was surveyed in 2012, without any prehistoric remains being recorded, and could not be investigated in 2014. The local site/soil quality was mapped in the 1960s and documented as an area with coniferous forest with a high site/soil quality, allowing easy cultivation. See https://kilden.nibio.no/?X=6553914.57\&Y= 192703.18\&zoom=13\&lang=nb\&topic=arealinformasjon\& bgLayer=graatone_cache\&catalogNodes $=2,13,325,199 \&$ layers_opacity $=0.7 \overline{5}, 0.75 \&$ layers $=$ dmk_dyrkbar_jord,hist_ gammel_ok_raster
} 


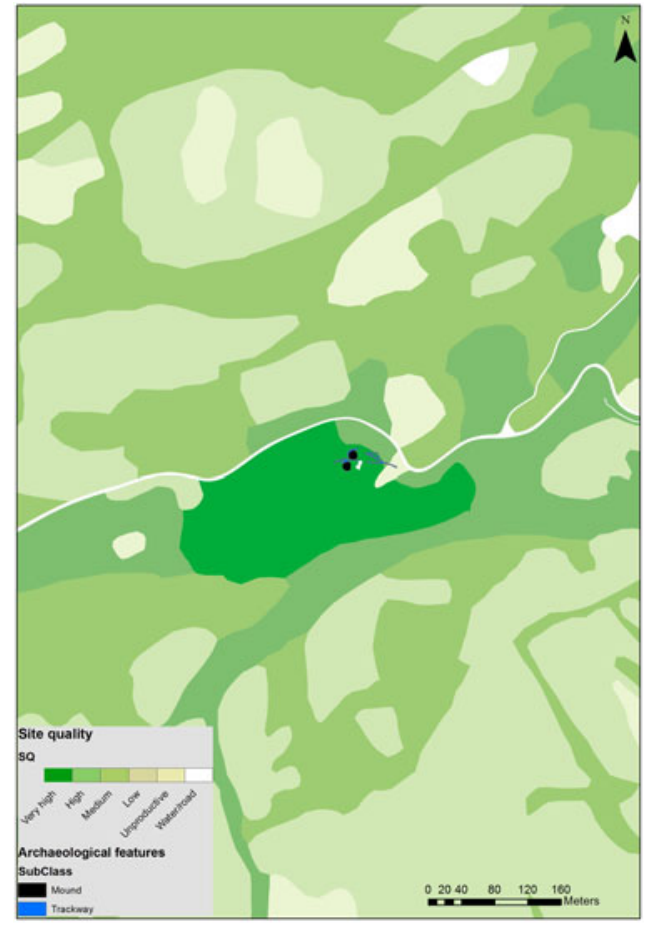

Figure 7. Map showing soil quality in the area around the excavations at Bamble. Dark green represents areas with coniferous forest and bigh site/soil quality that would allow easy cultivation. Source: https://kilden.nibio.no/? $X=6553914.57$ \& $Y=192703.18$ E'zoom $=13$ Elang $=n b$ E'topic $=$ areal informasjon E'bgLayer=graatone_cache Écatalog Nodes $=2,13,325,199$ Elayers_opacity $=0.75,0.75,0$. $75,0.75$ Elayers $=d m k \_d y r k b a r \_j o r d$, norgeibilder_2, bist_gammel_ok_raster,hist_kartid_dato

accounted for only a short-lived period of cultivation before the mound was constructed. He does not give an estimate of how fast the water table may have changed.

The preservation conditions on site explain the lack of seeds. In dry conditions, plant macrofossils require exposure to high temperatures to become preserved (charred or carbonized). Such opportunities are more common on settlements and this explains the absence of macro-botanical remains in the mounds. A field cleared by fire and manured with dung at Site 51 of the E18-project in Vestfold may serve as an example. Out of fifty-five samples, only fifteen produced burnt plant material, and only five burnt seeds were collected from the site (Viklund et al., 2013: 26-28, 53-58, and tables 67-68). A similar example can be found at the Roman-Saxon settlement at Scole in the Waveney valley, Suffolk, England (area 8). It produced no plant macrofossils, even though the soil micromorphology and pollen showed evidence of nightsoil cultivation, fallowing, and agriculture in the local area (Ashwin \& Tester, 2014: 199202, 402-03, 418-21, 425-31). Stijn Arnoldussen (2018: 310) also argues that low seed recovery rates in Celtic fields (1.5-5 charred seeds for every 100 litres) is not a result of small-sample bias, but of past agricultural strategies in which household debris (charcoal from firewood, burnt dung, etc.) was used as a manuring agent.

The regional pollen diagram from Skogtjern covers all prehistoric periods, but of interest here is the establishment of a farming community in the first millennium AD. Three major phases of expansion in the utilization of the catchment area are attested against a background of radiocarbon-dated material from the pollen core: these phases are dated cal AD 160-290, 310-570, and 610-950 (all dates at $2 \sigma$, OxCal v4.2.3, according to WieckowskaLüth et al., 2015, 2017). The first phase seems to be broadly contemporary with the ${ }^{14} \mathrm{C}$ dates of the possible cremation beneath the first mound (cal AD 130-330), and the third phase (cal AD 610-950) with the dates proposed for the later mound (Mound 1, cal AD 670-865). Furthermore, these periods are characterized by a general expansion and intensification of land use, as verified by extensive forest clearances and fires, crop cultivation on permanent fields, and the presence of open pastures as well as advanced soil degeneration and increased erosion rates (Wieckowska-Lüth et al., 2015, 2017). 
Additionally, the intra-site pollen shows that the mounds were established in an open landscape with fields, pastures, and nearby alder woods. Pollen from crop production, notably wheat, flax, and rye, are recorded, probably relating to production on the site before and contemporaneous with the mound construction (Linderholm et al., 2016). This also supports the radiocarbon dates of Mound 2 (cal AD 130330) being linked to the Roman Iron Age. Pollen from cereals generally only spread over a limited area (Behre, 1981: 226-28), and the presence of intra-site pollen indicates that cereals were grown and/or processed close to the mounds. Spruce is found only at Mound 1, indicating that it was built later than Mound 2 and after $\mathrm{AD}$ 550, when spruce was established locally according to the Skogtjern pollen diagram (Wieckowska-Lüth et al., 2015, 2017; Linderholm et al., 2016). This may also explain the lack of ard marks beneath Mound 1, as this was built some 600 years after Mound 2, allowing time for soil processes to erase the remaining furrows on the site.

In summary, there were two mounds, one dated to the Roman Iron Age (with a charcoal concentration or possible cremation dated to cal $\mathrm{AD}$ 130-330) and the other to the Viking Age (displaced bone and charcoal: cal $\mathrm{AD}$ 780-865). Micromorphology and pollen from both mounds clearly indicate cultivation of the land at the site before or at the same time as the construction of the mounds, thus indicating a connection between profane and ritual elements. Humic matter was extracted from the contents of one of the ard marks (cal AD 130-340) and gave almost the same dates as a charcoal concentration from the first mound (cal $\mathrm{AD}$ 130-330), suggesting that the mound was built within a few years after ploughing had stopped. The presence of cereals in the intra-site pollen analysis and the good quality of the soil are strong indicators that the ard marks represent a former field, and possibly a nearby settlement. This does still not exclude a ritual act in connection with the burial ceremony and the subsequent mound building. When the second mound was raised, the ploughmarks from the rest of the site had presumably been erased by natural processes. The ard marks probably survived beneath Mound 2 because of the extra layers of soil connected to the creation of the mound shortly after ploughing at the site. It is not possible to tell how long the field was in use as the ploughed soil may have been thicker during its lifetime and the 'single phase' may be a record of the deepest ard marks made during the lifetime of the ploughsoil. As will be discussed further, many prehistoric sites are characterized by raising a mound as a closing element (Gansum, 2004: 159-65; Stenholm, 2012). If this took place shortly after the field was abandoned, it would also explain why the ard marks survived.

In the Iron Age, a mound is likely to have been associated with many layers of meaning, and rituals associated with the mound construction may have been important for consolidating this meaning. The first mound at Bamble/Stillinga may have been built as a visible monument along a route that was also connected to the old field system and buried within the mound. For Bronze Age Denmark, Johansen and colleagues (2004: 38-39, 52) have shown that settlements, barrows, and roads were formed in a diachronic complex interplay, which in turn led to the formation of network lines, in effect spatial patterns of social organization. The monument at Bamble may relate to a once-known deceased, either as a burial or a cenotaph (as bones were missing). More importantly, the mound was built to tie the site to ancestral affiliation and the family's right to the land, linking it to the plot of land that was first 
farmed by (presumed or real) ancestors (Zachrisson, 1994; Skre, 1998: 290-91, 295, 297; Gansum, 2004: 195-99;). The first and second mounds may have been built to demonstrate presence of a kin and its social norms during a landnam period and a later re-establishment of rights to the land in the Viking Age. Consequently, the creation of a second mound must have exploited the original monument's importance, thus renegotiating a statement of authority and identity in the landscape (Thäte, 2007; Harrison, 2008; Artelius, 2013).

The ${ }^{14} \mathrm{C}$ dates of Mound 2, the agricultural clearance visible in the Skogtjern pollen diagram, and humic matter from the ard mark are all quite similar and span a couple of centuries in the early first millennium AD. Together they have helped resolve the order of events at the site. Moreover, the composition of the mound material demonstrates that, at the time the mound was built, there must have been a somewhat larger manured area than the area from which this material was taken. Similar stripping of turf and topsoil to create a mound is observed at the Viking Age site of Ballateare on the Isle of Man (Bersu \& Wilson, 1966: 48). Presumably, settlement activities form a good prerequisite for the cutting of turfs for barrow construction (Johansen et al., 2004: 39). At Sutton Hoo there were also ploughmarks below Mounds 2 and 5 (see Carver, 2005: 372-73, fig. 157, and pl. 52). In conclusion, a ritual connection to the domestic sphere seems to have been made by establishing a mound on top of a previously cultivated field. The ploughmarks testify to the arable use of land, and the following funerary ritual builds the connection with working the land. Similarly, the turfs used for building the Bronze Age Skelhøj mound derived from a dry to medium-dry heathland community at close vicinity to the mound (Karg, 2006;
Breuning-Madsen, 2013: 217, 226). This turf consisted almost solely of topsoil material and had a higher phosphorous content than unmanured sandy soils in Jutland (Breuning-Madsen, 2013: 220). In the lower anaerobic core, the decomposition of organic matter was very low and could be used to measure the level of organic remains (i.e. heather and dung beetles), which was slightly higher than on modern arable land (Breuning-Madsen, 2013: 227). The important role that material culture plays in reifying, remembering, and upholding the past (Williams, 2006: 3; Olsen, 2010: 110; Semple, 2013) is further explored below.

\section{An Overview of Ard Marks under Mounds in Norway and Scandinavia}

Ard marks under mounds are known from several sites in Norway, but they have rarely been the subject of detailed scientific analysis. Table 1 gives an overview of sites known to the author; most are undated due to investigations having been conducted before sampling and radiocarbon dating became common, but a few seem to indicate that the ard marks under the mound were fresh (Holerøysa has a very wide timeframe).

The same pattern of erecting mounds over prehistoric fields and houses is known from Sweden. The monumental grave 4 at Högom, Medelpad, Sweden, was typologically dated to the Late Roman-Migration period (AD 350-450) and covered well preserved ard marks as well as a house. The ard marks themselves were not dated, but the house that is stratigraphically earlier than the ard marks is dated by comparison with house 1 at Gene to the period AD 100-350, indicating a close relationship between the ploughing and the mound (Ramqvist, 1992: 191-215). In Lucksta, Attmar, Medelpad, a situation 
Table 1. Overview of Norwegian sites with ard marks under mounds.

\begin{tabular}{|c|c|c|c|c|c|}
\hline County & Municipality & Farm/site & Date of mound/cairn & $\begin{array}{l}\text { Dating of } \\
\text { cultivation layer/ } \\
\text { ard marks }\end{array}$ & References \\
\hline$\varnothing$ stfold & Halden & Gjellestad & $\begin{array}{l}\text { Ploughed mound only } \\
\text { shown by surround- } \\
\text { ing ditch, undated } \\
\text { (probably Iron Age; } \\
\text { remains of cultural } \\
\text { layer within ditch) }\end{array}$ & Undated & Berge, 2017 \\
\hline$\varnothing$ stfold & Fredrikstad & Hunn & $\mathrm{AD} 1-200$ & Undated & Herteig, 1954: 65 \\
\hline Østfold & Fredrikstad & $\begin{array}{r}\text { Grimstad } \\
\text { Nordre }\end{array}$ & $\mathrm{AD} 400-550$ & Undated & $\begin{array}{l}\text { Derrick \& Lønaas, } \\
2013\end{array}$ \\
\hline Østfold & Sarpsborg & Opstad & $\mathrm{AD} 3-400$ & Undated & Løken, 1978 \\
\hline$\varnothing$ stfold & Sarpsborg & Værn & $900-750 \mathrm{cal} \mathrm{вс}$ & $1600-1450 \mathrm{cal} \mathrm{BC}$ & $\begin{array}{l}\text { Kile-Vesik \& Lønaas, } \\
2017\end{array}$ \\
\hline Østfold & Sarpsborg & Borregård & AD $1-200$ & Undated & Helliksen, 1996 \\
\hline Østfold & Rygge & $\begin{array}{l}\text { Halmstad } \\
\text { (Voldskogen) }\end{array}$ & $\mathrm{AD} 2-400$ & $\begin{array}{l}\text { Undated, but pos- } \\
\text { sibly connected to } \\
\text { a layer dated } \\
575-390 \mathrm{cal} \text { BC } \\
\text { outside the } \\
\text { mound }\end{array}$ & $\begin{array}{l}\text { Skre, 1997: 15-17; } \\
\text { Orvik, } 2018\end{array}$ \\
\hline Akershus & Ullensaker & Raknehaugen & $\mathrm{cal} \mathrm{AD} \mathrm{540-580}$ & $\begin{array}{l}\text { Shortly before } \\
\text { construction }\end{array}$ & Skre, 1997: 15-17 \\
\hline Vestfold & Tønsberg & Gulli & $\begin{array}{l}\text { Ploughed mound only } \\
\text { shown by surround- } \\
\text { ing ditch, undated } \\
\text { (probably Iron Age; } \\
\text { traces of settlement } \\
\text { within ditch) }\end{array}$ & $1100-400 \mathrm{cal} \mathrm{BC}$ & $\begin{array}{l}\text { Glørstad \& Wenn, } \\
\text { 2013: 117-22 }\end{array}$ \\
\hline Vest-Agder & Lindesnes & Udland & $\begin{array}{l}\text { AD } 2-400 \\
\quad(4 \text { graves })\end{array}$ & $\begin{array}{l}\text { cal AD } 2-400 \\
\text { (shortly before } \\
\text { construction) }\end{array}$ & $\begin{array}{l}\text { Gjerpe, 2008: 198- } \\
\text { 205, 211-13; } \\
\text { Glørstad \& Wenn, } \\
\text { 2013: 117-22 }\end{array}$ \\
\hline Rogaland & Sola & Myklebust & $\mathrm{AD} 600-800$ & cal AD 1-250 & Dahl, 2016: 108 \\
\hline $\begin{array}{l}\text { Møre og } \\
\text { Romsdal }\end{array}$ & Sande & Holerøysa & $\begin{array}{l}\text { Grave 1: AD 800-1000 } \\
\text { Grave 2: AD 2-400 }\end{array}$ & $200 \mathrm{BC}-\mathrm{cal}$ AD 300 & $\begin{array}{l}\text { Johnson \& Prescott, } \\
\text { 1993: 74-79 }\end{array}$ \\
\hline $\begin{array}{l}\text { Møre og } \\
\text { Romsdal }\end{array}$ & Rauma & Åndalsnes & $\mathrm{AD} 400-550$ & Undated & $\begin{array}{l}\text { Binns, 1993: } 9 \text { with } \\
\text { further references }\end{array}$ \\
\hline Trøndelag & Stjørdal & Husby & Undated & $500-1 \mathrm{cal} \mathrm{BC}$ & $\begin{array}{l}\text { Binns, 1993: } 9 \text { with } \\
\text { further references }\end{array}$ \\
\hline Trøndelag & Grong & Veiem & $\mathrm{AD} 400-550$ & $\begin{array}{l}500-1 \text { cal вс (ard } \\
\text { marks and } \\
\text { cooking pits) }\end{array}$ & Farbregd, 1980 \\
\hline Nordland & Vestvågøy & Moland & $\mathrm{AD} 7-800$ & $\begin{array}{l}50 \mathrm{cal} \text { BC-cal AD } \\
100 \text {, covered by } \\
\text { cultivation layer } \\
\text { cal AD 400-550 }\end{array}$ & $\begin{array}{l}\text { Johansen, 1975: 18- } \\
\text { 21, 1979: 101-02, } \\
\text { 1990: } 29\end{array}$ \\
\hline
\end{tabular}

similar to that at Bamble was excavated in 1982. A large mound with two cremations dated to the Late Iron Age had been built over a smaller stone setting with an Early
Iron Age cremation burial and parts of two prehistoric buildings dated to the Early Iron Age and Early Roman Iron Age (AD 1-200). Some $20 \mathrm{~cm}$ below the 
stone setting, the excavators found ard marks dated to the Early Roman/PreRoman period, suggesting remarkable continuity throughout the whole of the Iron Age (Broadbent, 1985). At Vinarve, Rone, Gotland, a cairn with a burial within a stone cist dated to the Late Roman Iron Age (AD 250-350) overlay ard marks (Lindqvist, 1974: 19-21) dated to the pre-Roman Iron Age (c. $150 \mathrm{BC}$ ), but the field was probably in use for a long period, building up a thick cultivation layer. Similar ard marks have also been found under the remains of buildings dated to the Iron Age, including those at Vallhagar, Gotland (Stenberger, 1979: 462, 569).

The phenomenon of mounds built over former fields is not limited to the Iron Age; and, in fact, most Danish examples are dated to the Bronze Age (Thrane, 1991; Nielsen, 1993: 208). The phenomenon is also documented in Germany, Great Britain, the Netherlands, Poland, and Switzerland (Thrane, 1991: 117 with further references). Thus, it seems that ard marks under burial mounds are a common phenomenon throughout Scandinavia, given good preservation conditions. Most burial mounds in Norway were excavated before 1950, when knowledge of the phenomenon became common. I believe that the presence of ard marks under mounds is somewhat underrepresented in the record and that the choice of sites for burial mounds in the Iron Age of Scandinavia was heavily based on a previous use of the landscape and prior claims to the land, as discussed below.

\section{Site Reuse and Connection Between Ritual AND Domestic Life}

When the two burial mounds were found by surveys at Bamble, it raised the question: why was this place chosen? What characterized the place at the time the mounds were built? The location is close to the boundary between two farms (Hydal and Bamble Prestegård). For Scandinavian contexts, Torun Zachrisson (1994), Dagfinn Skre (1998), and Frode Iversen (2008) have claimed that burial in boundary zones might indicate property rights. Lars Erik Gjerpe (2014, 2017), on the other hand, has recently argued that there is no solid evidence that modern farm boundaries were established in the Early Iron Age. Gjerpe's (2014) study of excavated farmsteads from Vestfold and comparative material concluded that the Early Iron Age farm sites in Norway seem to have moved around, and that strict farmland boundaries were a later phenomenon. In our case, the former farmland rather than the boundaries seems to be responsible for the initial placement of the oldest monument (Mound 2). Even though the ploughmarks were not a part of the ritual, it is still plausible that the reason why the mound was erected at this particular site was to create a link with the contemporary cultivated field and a possible rural settlement, thus connecting the ritual and profane aspects of life. This is also true for many Danish Bronze Age mounds that seem to connect to either visible fields or old settlements (Nielsen, 1993: 169-87; Bradley, 2005: 25-28). Similarly, Stephen Harrison and Ragnhall ÓFloinn draw attention to the relationship between burial sites and territorial markers or access points with graves at Dublin (Harrison \& Ó'Floinn, 2014). Even if the mounds do not mark a farm boundary, they could still be boundary markers. Mound 2 at Bamble/Stillinga may have marked the edge of the ground that was fertile enough to farm. Even though the plot of land immediately connected to the mounds was abandoned after a few ploughing episodes, possibly because of a higher water table, the site must have 
remained an important place. Another possibility is that the site changed from arable to pastoral in connection with the erection of the mound. Indeed, the piece of land next to the mounds at Bamble/ Stillinga was probably continuously used for agricultural purposes at least until the second mound was built if not also in the following decades (cf. Arnoldussen's (2018) recent study of the high sustainability and longevity of agricultural practices in the later prehistoric Netherlands). A central element in the appropriation of the past is that it is an active and creative practice that involves interactions with memory and concrete material phenomena (Williams, 2013: 197; Lund \& ArwillNordbladh, 2016: 416). For the mound to have an immediate social or ritual relevance, human activity in the area must have continued, both on the track and possibly with pastoral activities and/or farming continuing on drier land nearby.

Prehistoric societies oriented their actions in the present with respect to the past (Bradley \& Williams, 1998). For example, creating marks in the landscape, or reusing old marks, seems to have been an important set of actions that may have been highly formalized or ritualized, perhaps a way of giving ancient landscape features new values in a contemporary setting. Howard Williams (1998) argues that both Roman and prehistoric structures provided the focus of cemeteries, burial groups, and single graves in the period AD 400-700. The practice was central to Anglo-Saxon mortuary practices and important for the construction and negotiation of origin myths, identities, and social structures (Williams, 1998: 90). Over the past two decades, the study of the past in the past has become a well-established research area in Anglo-Saxon and Nordic archaeology for the period of AD 1-1000 (Williams, 2006, 2013; Jones, 2007; Andrén, 2013; Artelius, 2013; Semple, 2013). Death and burial provide an important context through which social memories and identities were performed and created in societies experiencing social, political, and religious transformations (Williams, 2006: 3; Semple, 2013: 3-6). Both the Bamble site and other Scandinavian examples demonstrate how people in prehistory used well-known sites and features in the local topography to mark and legitimize ownership of the land.

It seems to be a conscious choice to embed the dead in the past and link them to an older landscape, thereby making a statement of authority or ownership (Thäte, 2007; Harrison, 2008). A recent study by Ann-Mari Hållans Stenholm (2012) takes this further as she includes settlements or buildings (see also Gansum, 2004: 159-65; Eriksen, 2016; Dahl, 2016), showing how each context is intended to create, transfer, and preserve memory by reusing the site of an earlier grave or building via superimposition. In this context, reuse legitimizes ownership and status (Stenholm, 2012: 37-44 with further references) by creating an idealized, naturalized, and seamless connection with the past (Holtorf, 1998: 24).

Interestingly, in Stenholm's (2012: 6175) critical reading of the term memory in the Icelandic Sagas and Eddas, memory and the past are shown to have been fundamental forces. The farm, as a concept and phenomenon, seems to have been central to people's conception of the world during the Iron Age and early Middle Ages. Even if Stenholm mainly links building remains to the concept of the farm, I would argue here that prehistoric fields are just as important for the memory of the farm and the reason for constructing a mound in an older landscape.

Richard Bradley (2005) finds that there is so much overlap in ritual and domestic life that archaeologists have difficulties separating the two spheres. The deliberate placement of mounds over remains of structures from the past directs the focus 
to these structures and encompasses how memory is reproduced (Jones, 2007: 159), thereby making a ritual connection to the domestic landscape. Landscape and material cultures do not provide a mere stage for human action but create a set of locales integral to that action (Gosden \& Lock, 1998: 4). While breaking land for agriculture is a domestic process, laying claim to cultivated land or space may have been a ritualized act. To use the cultivated soils as building material in a mound to claim ownership at the expense of good agricultural soils is an even more significant action. At Bamble/Stillinga, the claiming of land may have been more important than the burial itself, possibly explaining the lack of grave goods. The mound may not even have contained a burial. It should be seen as a monument with an ancestral connection, the transformation of the farmland representing a demarcation where a deceased individual is secondary to the wider social network of the farm.

Relating to and reinterpreting the past to demonstrate power, and establish and maintain relationships (Lund \& ArwillNordbladh, 2016: 431), illustrates that a significant bond between cultivation and the treatment of the dead existed in the past. In some cases, the position of a grave on an earlier field may be the only indication, but marking the ground by ploughing or by aligning a grave along furrows has also been documented (Bradley, 2005: 35). Additionally, artefacts associated with daily life are often found in ritual contexts (e.g. burials), providing an opportunity to gain a more rounded view of prehistory. In the case of Bamble, no artefacts were found, but the plough furrows refer to the use of an ard in a domestic context. Bradley's (2005) discussion of the construction of rituals against the background of materials and artefacts of domestic life was taken up by Andrew Jones (2007: 80-84), who established how artefacts belong to networks of 'referenciality' that extend through time with different degrees of endurance and significance. Although the ard is a domestic implement, this tool was associated with ritual activities as late as the early 1900s, alongside seeds for sowing and the ploughing process itself (Davidson, 1959). The connection between mortality, the commemoration of the dead, and the agricultural cycle has been variously emphasized in different parts of Europe, where connections between burials and houses, pits, farmyards, fields, wells, and storage pits have been documented (Bradley, 2005: 204-05). In sum, linking to and honouring the past have been important factors in the establishment of mounds and monuments. In our case study, the relationship between mound and cultivated field within the local landscape was the decisive factor: one could not have existed without the other. The field acted as a visible time mark in the landscape, referring people back to the distant past and prompting them to treat these monuments in a particular way (Holtorf, 1998: 34).

The first mound at Bamble/Stillinga was built at a time when rights to land became manifest in the landscape and a restructuring of the settlement pattern was underway. When the second mound was erected, these rights were presumably under renegotiation during a period of further reorganization (see for example Zachrisson, 2011). In a turbulent period, when the cultural landscape was renegotiated and new farms created, a sociallyconstructed memory founded on the people who had established their claim to the land probably played a crucial role (Skre, 1998; Stenholm, 2012: 223-26).

Whether or not the association with the prehistoric field was relevant when the second mound was built some 500-600 years later is difficult to ascertain; but the first mound may have acted as a landmark, so that the site and ancestral connection 
was remembered by the living for many years. The work of Stenholm (2012: 22630) shows that a 'historical interest' was part of a general phenomenon across Western Europe during the Iron Age and that creating a genealogy and origin rooted in the Early Iron Age, and especially the Migration period, was actively pursued. Thus, the second mound was probably built to relate to the first along a route through the landscape, ending at the site where Bamble church was established in the twelfth century. As for Zachrisson's, Skre's, and Iversen's ideas about burials as property markers on the boundary between farms, this interpretation appears more relevant to the Viking Age mound (Mound 1) at Bamble, erected after the establishment of stricter farmland boundaries (Zachrisson, 2011; Gjerpe, 2014).

As the review of sites has demonstrated, ard marks are not uncommon under burial mounds in Scandinavia. The Bamble case study has shown that intensive sampling is of great value for our understanding of the stratigraphy and prehistoric use of the site in a long-time perspective. An important outcome of the sampling campaign was that soils from a former manured field were used as building material. Future investigations at similar sites should include discussion of the implications of using cultivated soils as building material in a mound to claim ownership at the expense of good agricultural soils (cf. the Skelhøj mound, Breuning-Madsen, 2013; Holst, 2013). It would also be highly relevant to explore the landscape around the mounds and thereby connect similar sites to preserved field systems or possibly settlements.

\section{ACKNOWLEDGEMENTS}

My thanks go to Johan Linderholm and Richard Macphail for valuable discussions on the sampling of the Bamble site, to the
University of Kiel for making the pollen core from Skogstjern available, and to the excavators for making the Bamble excavations a memorable ritual act of everyday life. I would like to thank Johan Arntzen, Jakob Kile-Vesik, Trond Meling, Morten Ramstad, Kathryn Etta Sæther, and Camilla Cecilie Wenn for insights on sites with ard marks under mounds in Norway. I am also thankful for the comments of the anonymous reviewers who helped develop the arguments in this article and link the research questions to current discourse.

\section{REFERENCES}

Andrén, A. 2013. Places, Monuments, and Objects: The Past in Ancient Scandinavia. Scandinavian Studies, 85: 267-81. https:// doi.org/10.5406/scanstud.85.3.0267

Arnoldussen, S. 2018. The Fields that Outlived the Celts: The Use-histories of Dutch Later Prehistoric Field Systems (Celtic Fields or Raakakkers) in the Netherlands. Proceedings of the Prehistoric Society, 84: 303-27. https://doi.org/10.1017/ppr.2018.5

Artelius, T. 2013. Inventions of Memory and Meaning: Examples of Late Iron Age Reuse of Bronze Age Monuments in South-Western Sweden. In: D.R. Fontijn, K. Wentink, A.J. Louwen \& S. Van der Vaart, eds. Beyond Barrows: Current Research on the Structuration and Perception of the Prehistoric Landscape through Monuments. Leiden: Sidestone, pp. 21-40.

Ashwin, T. \& Tester, A. 2014. A Roman Settlement in the Waveney Valley: Excavations at Scole, 1993-4 (East Anglian Archaeology, 152). Norwich: NPS Archaeology; Dereham: Norfolk Historic Environment; Bury St Edmunds: Suffolk County Council.

Behre, K.-E. 1981. The Interpretation of Anthropogenic Indicators in Pollen Diagrams. Pollen et spores, 23: 225-45.

Berge, J. 2017. Arkeologsk registrering. 2016/ 10949, Vestre Berg, Halden kommune. Unpublished report. Østfold fylkeskommunes archives. Sarpsborg.

Bersu, G. \& Wilson, D.M. 1966. Three Viking Graves in the Isles of Man. London: Society for Medieval Archaeology. 
Binns, K.S. 1993. Fra horn til korn. Om forholdet mellom husdyrhold og korndyrkning i vårt eldste jordbruk. Spor, 8: 8-10. https://www.ntnu.no/c/document_library/ get_file?uuid=4f0e7edd-96d4-4545-853c3a8e81479ae3\&groupId $=10476$

Bradley, R. 2005. Ritual and Domestic Life in Prehistoric Europe. London: Routledge.

Bradley, R. \& Williams, H. eds. 1998. The Past in the Past: The Reuse of Ancient Monuments. (World Archaeology, 30). London: Routledge. https://www.tandfonline.com/toc/rwar20/30/1?nav=tocList

Breuning-Madsen, H. \& Dalsgaard, K. 2013. Soil Processes in the Skelhøj Mound. In: M.K. Holst \& M. Rasmussen, eds. Skelhøj and the Bronze Age Barrows of Southern Scandinavia. Vol. 1: The Bronze Age Barrow Tradition and the Excavation of Skelhøj (Jutland Archaeological Society Publications, 78). Moesgård: Jysk Arkæologisk Selskab, pp. 217-30.

Broadbent, N. 1985. New Knowledge of Early Iron Age Settlement in Northern Sweden: Cooperation between the University of Umeå and the Västernorrland County Museum. In: E. Baudou \& M. Backe, eds. In honorem Evert Baudou (Archaeology and Environment, 4). Umeå: University of Umeå, pp. 387-93.

Caland, W. 1896. Die Altindischen Todtenund Bestattungsgebräuche mit Benützung handschriftlicher Quellen dargestellt. Amsterdam: J. Müller.

Carver, M.O.H. 2005. Sutton Hoo: A SeventhCentury Princely Burial Ground and its Context (Report of the Research Committee of the Society of Antiquaries of London, 69). London: British Museum.

Dahl, B. 2016. Relations Between Burials and Buildings in the Iron Age of Southwest Norway. In: F. Iversen \& H. Petersson, eds. The Agrarian Life of the North, 2000 $B C-A D$ 1000: Studies in Rural Settlement and Farming in Norway. Kristiansand: Portal, pp. 93-116. https://press.nordicopenaccess. no/index.php/noasp/catalog/book/13

Davidson, T. 1959. Plough Rituals in England and Scotland. The Agricultural History Review, 7: 27-37.

Derrick, M. \& Lønaas, O.C. 2013. Rapport arkeologisk utgravning. Bosetningsspor og gravminne Grimstad nordre 670/3, Fredrikstad, Østfold. Unpublished report. Oslo: Kulturhistorisk museums arkiv.
Eriksen, M.H. 2016. Commemorating Dwelling: The Death and Burial of Houses in Iron and Viking Age Scandinavia. European Journal of Archaeology, 19: 477-96. https://doi.org/10.1080/14619571.2016. 1186918

Farbregd, O. 1980. Perspektiv på Namdalens jernalder. Viking, 53: 20-80. https://www. duo.uio.no/handle/10852/37632

Field, D. 2006. Earthen Long Barrows: The Earliest Monuments in the British Isles. Stroud: Tempus.

Fowler, P.J. 2002. Farming in the First Millennium AD: British Agriculture Between Julius Caesar and William the Conqueror. Cambridge: Cambridge University Press.

Gansum, T. 2004. Hauger som konstruksjonerarkeologiske forventninger gjennom 200 år. Göteborg: Göteborg University.

Gjerpe, L.E. 2008. Kapittel 5. Gulli 5 og 15 - Bosetningsspor, dyrkningsspor, smie og graver fra bronsealder, jernalder og middelalder. In: L.E. Gjerpe, ed. E18-prosjektet Vestfold : Bind 3: Hus, boplass- og dyrkningsspor Oslo: Kulturhistorisk museum, Fornminneseksjonen, pp. 195-224.

Gjerpe, L.E. 2014. Kontinuitet i jernalderens bosetning. Et utdatert postulat arvet fra 1814-generasjonen? Viking, 77: 55-78. https://www.duo.uio.no/handle/10852/48992

Gjerpe, L.E. 2017. Effektive hus : bosetning, jord og rettigheter på Østlandet i jernalder. 2 bind (unpublished $\mathrm{PhD}$ dissertation, Institutt for arkeologi, konservering og historie, det humanistiske fakultet, Universitetet i Oslo).

Glob, P.V. 1951. Ard og plov i Nordens oldtid. Aarhus: Universitetsforlaget i Aarhus.

Glørstad, Z. \& Wenn, C.C. 2013. En gambler langs veien; nytt blikk på grav og gravritualer i eldre jernalder. Viking, 76: 113-36. https://www.duo.uio.no/handle/ $10852 / 43696$

Gosden, C. \& Lock, G. 1998. Prehistoric Histories. World Archaeology, 30: 2-12. https://doi.org/10.1080/00438243.1998. 9980393

Guilaine, J. 1991. Pour une archéologie agraire. Paris: Armand Collin.

Hagen, A. 1985. Om ard, kornavl og bosetningsutvikling. Viking, 48: 44-69. https:// www.duo.uio.no/handle/10852/37608

Harrison, S.H. 2008. Separated from the Foaming Maelstrom: Landscapes of Insular 'Viking' Burial. In: S. Semple \& 
H. Williams, eds. Anglo-Saxon Studies in Archaeology and History: Early Medieval Mortuary Practices. Oxford: Oxford University School of Archaeology, pp. 61-72.

Harrison, S.H. \& Ó'Floinn, R. 2014. Viking Graves and Grave-Goods in Ireland. Dublin: National Museum of Ireland.

Hatt, G. 1941. Forhistoriske plovfurer i Jylland. Aarboger for nordisk oldkyndighed og historie, 1941: 155-65.

Helliksen, W. 1996. Kvinnegrav fra eldre romertid; ardpløyd åker og hus. Viking, 59: 45-62. https://www.duo.uio.no/handle/ $10852 / 37617$

Herteig, A.E. 1954. Romertids gravanlegg; ardfurer og åkerbruk. En foreløpig melding om gravninger på Hunn i Østfold 195152. Viking, 18: 51-68. https://www.duo. uio.no/handle/10852/37581

Holst, M.K. \& Rasmussen, M. 2013. Skelhøj and the Bronze Age Barrows of Southern Scandinavia. Vol. 1: The Bronze Age Barrow Tradition and the Excavation of Skelhøj (Jutland Archaeological Society Publications, 78). Moesgård: Jysk Arkæologisk Selskab.

Holtorf, C.J. 1998. The Life Histories of Megaliths in Mecklenburg-Vorpommern (Germany). World Archaeology, 30: 23-38. https://doi.org/10.1080/00438243.1998. 9980395

Homer, 1955. Homer's Iliad [Ilias] (Transl. S.O. Andrew \& M.J. Oakley). Everyman's Library no. 453. London: Dent.

Iversen, F. 2008. Eiendom, makt og statsdannelse: kongsgårder og gods $i$ Hordaland $i$ yngre jernalder og middelalder (Universitetet i Bergen Arkeologiske Skrifter, 6). Bergen: Universitetet i Bergen.

Johansen, K.L., Laursen, S.T. \& Holst, M.K. 2004. Spatial Patterns of Social Organization in the Early Bronze Age of South Scandinavia. Journal of Anthropological Archaeology, 23(1): 33-55.

Johansen, O.S. 1975. Arkeologiske undersøkelser på Moland, Vestvågøy k. Nordland 1975. Unpublished report. Tromsø: Tromsø Museum and Tromsø University Museum.

Johansen, O.S. 1979. Jernaldergårder i NordNorge. In: R. Fladby \& J. Sandnes, eds. $P a ̊$ leiting etter den eldste garden. Oslo: Universitetsforlaget, pp. 95-117.
Johansen, O.S. 1990. Synspunkter på jernalderens jordbrukssamfunn i Nord-Norge. Tromsø: Universitetet i Tromsø.

Johnson, T. \& Prescott, C. 1993. Late Neolithic Houses at Stokkset, Sande in Sunnmøre. In: B. Solberg, ed. Minneskrift Egil Bakka (Arkeologiske Skrifter 7 fra Historisk Museum). Bergen: University of Bergen, pp. 70-89.

Jones, A. 2007. Memory and Material Culture: Tracing the Past in Prehistoric Europe. Cambridge: Cambridge University Press.

Kaland, S., Hillern Hanssen 1971. Studier i Øvre Telemarks Vikingtid. Universitetets Oldsaksamling Arbok, 1969: 67-216.

Karg, S. 2006. Direct Evidence of Heathland Management in the Early Bronze Age (14th Century BC) from the Grave-mound Skelhøj in Western Denmark. Vegetation History and Archaeobotany, 17: 41-9. https:// doi.org/10.1007/s00334-007-0109-7

Kile-Vesik, J. \& Lønaas, O.C. 2017. Gravhög, Værn, 1026/2, Sarpsborg K., Østfold. Unpublished report. Oslo: Kulturhistorisk museums arkiv.

Kristiansen, K. 1990. Ard Marks Under Barrows: A Response to Peter RowleyConwy. Antiquity, 64: 322-27. https://doi. org/10.1017/S0003598X00077978

Linderholm, J., Wallin, J.-E., Östman, S. \& Eriksson, S. 2016. Miljöarkeologiska laboratoriet. Rapport nr. 2016-006. Miljöarkeologiska analyser av jord- och sedimentprover från gravkontexter vid Bamble prestegård 41/1, Telemark, Norge. Unpublished report. Umeå: Umeå universitet.

Lindqvist, S.-O. 1974. The Development of the Agrarian Landscape on Gotland in the Early Iron Age. Norwegian Archaeological Review, 7: 6-32. https://doi.org/10.1080/ 00293652.1974 .9965197

Løken, T. 1978. Nye funn fra et gammelt gravfelt. Kan gård og boplass gå tilbake til eldre bronsealder? Viking, 41: 133-65. https://www.duo.uio.no/handle/10852/37603

Lund, J. \& Arwill-Nordbladh, E. 2016. Divergent Ways of Relating to the Past in the Viking Age. European Journal of Archaeology, 19: 415-38. https://doi.org/ 10.1080/14619571.2016.1193979

Macphail, R. 2015. Report from Micromorphological Analysis at Stillinga, Bamble, 
Telemark. Unpublished report. London: UCL.

Milisauskas, S. 2002. European Prehistory: A Survey. Dordrecht: Springer.

Munch, J.S. 1965. Borg og bygd. Studier i Telemarks eldre jernalder. Universitetets Oldsaksamling Arbok, 1962: 7-175.

Nielsen, V. 1993. Jernalderens plojning: Store Vildmose. Hjørring: Vendsyssel Historiske museum.

Olsen, B. 2010. In Defense of Things: Archaeology and the Ontology of Objects. Lanham (MD): AltaMira.

Orvik, K. 2018. Rapport arkeologisk utgravning. Gravfelt og bosetningsspor, Garder østre, 166/21, 32, 71, Ullensaker kommune, Akershus. Unpublished report. Oslo: Kulturhistorisk museums arkiv.

Pätzold, J. 1960. Rituelles Pflügen beim vorgeschichtlichen Totenkult - Ein alter indogermanischer Bestattungsbrauch? Praehistorische Zeitschrift, 38: 189-239.

Ramqvist, P.H. 1992. Högom: The Excavations 1949-1984. Neumünster: Wachhholtz.

Reynolds, P.J. 1981. Deadstock and Livestock. In: R. Mercer, ed. Farming Practice in British Prehistory. Edinburgh: Edinburgh University Press, pp. 97-122.

Rødsrud, C.L. 2017. E18 Rugtvedt-Dørdal delrapport. Gravhauger og hulveier, Bamble prestegård med Lønneråg, 41/1, Bamble kommune, Telemark. In: S. Solheim, ed. E18 Rugtvedt-Dørdal. Arkeologiske undersøkelser av lokaliteter fra steinalder og jernalder $i$ Bamble kommune, Telemark fylke. Kristiansand: Portal, pp. 557-88.

Rowley-Conwy, P. 1987. The Interpretation of Ard Marks. Antiquity, 61: 263-66. https://doi.org/10.1017/S0003598X00052091

Semple, S. 2013. Perceptions of the Prehistoric in Anglo-Saxon England: Religion, Ritual, and Rulership in the Landscape. Oxford: Oxford University Press.

Skre, D. 1997. Raknehaugen. En empirisk loftsrydding. Viking, 60: 7-42. https:// www.duo.uio.no/handle/10852/37618

Skre, D. 1998. Herredommet: bosetning og besittelse på Romerike 200-1350 E. KR. (Acta humaniora, 32). Oslo, Universitetsforlaget.

Solberg, B. 2000. Jernalderen i Norge: ca. $500 \mathrm{f}$. Kr.-1030 E.KR. Oslo: Cappelen Akademisk.

Sørensen, L. \& Karg, S. 2012. The Expansion of Agrarian Societies Towards the North: New Evidence for Agriculture During the Mesolithic/Neolithic Transition in Southern
Scandinavia. Journal of Archaeological Science, 51: 98-114. https://doi.org/10.1016/j.jas. 2012.08.042

Stenberger, M. 1979. Det forntida Sverige. Stockholm: AWE/Gebers.

Stenholm, A.M.H. 2012. Fornminnen: det forflutnas roll $i$ det forkristna och kristna Mälardalen. Lund: Nordic Academic Press.

Thäte, E.S. 2007. Monuments and Minds: Monument Re-use in Scandinavia in the Second Half of the First Millennium $A D$ (Acta archaeologica lundensia, 27). Lund: Wallin \& Dalholm.

Thrane, H. 1991. Danish Plough-Marks from the Neolithic and Bronze Age. Journal of Danish Archaeology, 8: 111-25. https://doi.org/10.1080/0108464X.1989. 10590023

van Giffen, A.E. 1940. Oudheidkundige aantekeningen over Drentsche vondsten. Nieuwe Drentsche Volksalmanak, 58: 180-216.

Viklund, K., Linderholm, J. \& Macphail, R.I. 2013. Palaeoenvironmental Study: Microand Macrofossil Analysis and Geoarchaeology (Soil Chemistry, Magnetic Susceptibility, and Micromorphology). In: L.E. Gjerpe, ed. E18-prosjektet Gulli-Langåker. Oppsummering og arkeometriske analyser, Bind 3. Oslo: Fagbokforlaget, pp. 25-83.

Wieckowska-Lüth, M., Dörfler, W. \& Kirleis, W. 2015. A More Than 10,500 Years High-resolution Record of Vegetation History and Dynamics, Human Impact, and Erosion History from Lake Skogtjern, Southern Norway. Unpublished report. Kiel: Institute of Pre- and Protohistoric Archaeology, Christian-Albrechts University. Wieckowska-Lüth, M., Kirleis, W. \& Dörfler, W. 2017. Holocene History of Landscape Development in the Catchment of Lake Skogstjern, Southeastern Norway, Based on a High-resolution Multi-proxy Record. The Holocene, 27: 1928-47. https://doi.org/ 10.1177/0959683617715691

Williams, H. 1998. Monuments and the Past in Early Anglo-Saxon England. World Archaeology, 30: 90-108. https://doi.org/ 10.1080/00438243.1998.9980399

Williams, H. 2006. Death and Memory in Early Medieval Britain. Cambridge: Cambridge University Press.

Williams, H. 2013. Death, Memory, and Material Culture: Catalytic Commemoration 
and the Cremated Dead. In: S. Tarlow \& L. N. Stutz, eds. The Oxford Handbook of the Archaeology of Death and Burial. Oxford: Oxford University Press, pp. 195-208. https://doi.org/10.1093/oxfordhb/97801995 69069.013.0011

Zachrisson, T. 1994. The Odal and its Manifestations in the Landscape. Current Swedish Archaeology, 2: 219-38. http://www. arkeologiskasamfundet.se/csa/Dokument/ Volumes/csa_vol_2_1994/csa_vol_2_1994_ s219-238_zachrisson.pdf

Zachrisson, T. 2011. Property and Honour: Social Change in Central Sweden, 200-700 $\mathrm{AD}$ Mirrored in the Area around Old Uppsala. In: L. Boye, ed. Arkeologi $i$ Slesvig: Sonderband 'Det 61. Internationale Sachsensymposion 2010' Haderslev, Danmark. Neumünster: Wachholtz, pp. 141-56.

\section{Biographical Note}

Christian Løchsen Rødsrud is based in the Museum of Cultural History at the University of Oslo, where he currently works as an advisor and regularly leads archaeological excavation projects. He completed his $\mathrm{PhD}$ at the University of Oslo in 2012 on the topic of Iron Age pottery and the ritualized feasting culture of the elite.

Address: Christian Løchsen Rødsrud, Museum of Cultural History, Postboks 6762 St Olavs plass, 0130 Oslo, Norway. [email: chrislro@khm.uio.no]. ORCID: 000-0002-2136-0692.

\section{Tertres funéraires, sillons d'araire et mémoire : une étude de cas du premier Age du Fer à Bamble, Telenark, Norvège}

Les fouilles de deux tertres funéraires et d'un système de chemins à Bamble (Telemark) en Norvège constituent le point de départ de cette étude. La découverte de sillons d'araire sous un des tumuli a mené l'auteur à s'interroger sur ce phénomène : ces sillons sont-ils le résultat d'un labourage rituel ou représentent-ils un ancien système parcellaireUne stratégie d'échantillonnage et l'analyse des données archéométriques indiquent que le tertre le plus ancien était lié à un système parcellaire, tandis que le tertre le plus récent avait été construit 500-600 ans plus tard. Le premier tumulus avait probablement été érigé pour marquer la présence d'une famille ou tribu et ses normes sociales, et ce sont ces normes qui ont été renégociées lors de la construction du second tumulus à l'époque viking. Alors que les recherches antérieures ont préféré soit sur un scénario profane soit une activité rituelle pour expliquer la présence de sillons d'araire sous les tertres, l'auteur souligne que les deux aspects sont étroitement liés : la construction d'un tertre peut représenter une pratique rituelle visant à légitimer un rang social et un droit de propriété en réaménageant des sites domestiques bien connus dans le paysage. Une série d'exemples scandinaves indique qu'il s'agit d'une pratique courante mais quelque peu négligée par la recherche. Translation by Madeleine Hummler

Mots-clés: sillons d'araire, tertres funéraires, réaménagement de sites, mémoire sociale, le passé dans le passé. Premier âge du Fer, Norvège, Scandinavie

\section{Grabhügel, Hakenpflugfurchen und Gedächtnis: eine Fallstudie der frühen Eisenzeit in Bamble, Telemark, Norwegen}

Die Ausgrabungen zweier Grabhügel und eines Wegsystems in Bamble, Telemark, Norwegen, bilden den Ausgangspunkt für diese Studie. Hakenpflugfurchen wurden unter einem Hügel entdeckt, was zu Fragen über die Nutzung der Stätte gefübrt hat: Hat man sie rituell gepflügt oder enthält sie die Überreste eines alten Feldsystems? Eine Serie von gezielten Proben und die Analyse der archäometrischen Daten haben gezeigt, dass der erste Grabhügel mit einem Feldsystem verknüpft war; der zweite wurde hingegen 500 oder 600 Jahre später errichtet. Der Grund für die Errichtung des ältesten Grabhügels war wahrscheinlich, um Verwandtschaft und soziale Normen zu demonstrieren, 
während diese Normen beim Bau des zweiten Grabhügels in der Wikingerzeit neu verhandelt wurden. Während die frühere Forschung entweder eine profane oder eine rituelle Erklärung für die Anwesenheit von Hakenpflugfurchen unter Grabhügeln betont hat, wird in diesem Artikel unterstrichen, dass die beiden Aspekte eng verbunden waren: Die Errichtung von Grabhügeln kann einen ritualisierten Gebrauch darstellen, welcher den Besitz und den sozialen Stand durch die Wiedernutzung von bekannten Standorten in der Landschaft legitimieren sollten. Weitere Beispiele aus Skandinavien zeigen, dass dieses Phänomen ein weitverbreiteter Gebrauch war, der allerdings von der Forschung etwas vernachlässigt ist. Translation by Madeleine Hummler

Stichworte: Hakenpflugfurchen, Grabhügel, Wiedernutzung von Stätten, soziales Gedächtnis, Vergangenheit in der Vergangenheit, frühe Eisenzeit, Norwegen, Skandinavien 